\title{
COLLABORATION AS A FORM OF KNOWLEDGE-BASED ECONOMY ORGANIZATION
}

The object field of knowledge-based economy is formed by appropriate real system of relations in production, distribution, exchange, and consumption reflecting its innovative and creative character. The variety of forms of institutions, organizations, and information are becoming the factors of the structuring, functioning, and evolving of knowledge-based economy in a global scale. Collaboration is attracting more and more attention from both researchers and experts in economics, politics, law, sociology, culture as a fast emerging and efficient but underexplored form of relations among subjects of knowledge-based economy. Collaboration is an appropriate to the nature of knowledge-based economy form of cooperation, which is detailed according to its subjects, objects, levels, and scale, spheres and industries, sectors and segments. Collaboration provides both intensive and extensive development of VI technological mode creating totally new types and generations of products and services. The diversity of local and regional, inter-firm and international forms of collaboration is accelerating in all spheres of global economy. Despite over simplifying, contemporary science has to think over the essence and evolutionary potential of collaboration as well as to work out justified recommendations for the practice.

Keywords: knowledge-based economy, collaboration, nanoeconomics, megaeconomics, megaprojects, megascience center, VI technological mode, product generations.

\section{Introduction}

The present stage of development of the global economic system (GES) is characterized as the unique stage of its evolution - knowledge-based economy, which sometimes is defined as the highest phase of the post-industrial society development. The dominating factor of production in the knowledge-based economy is the human capital with creative and innovative potential. This potential is implemented in products with a prevailing share of intellectual component. Last decade of XX century, the average annual investments in the knowledge grew quicker in OECD countries (3.4\%) than investments in fixed assets (2.2\%). Out of all volumes of the knowledge measured in physical units, which mankind has $90 \%$ are re- 
ceived for the last 30 years, just as $90 \%$ our of a total number of scientists and engineers trained for all history of civilization, - our contemporaries. These are the most obvious signs of the economic transition based on the use of natural resources and routine equipment to the knowledge-based economy [13].

Knowledge-based economy may be estimated as «ex ante» on the basis of assessment of the total investments in the development sector making and extending new knowledge, and as «ex post» - according to a share of a gross value added of branches, which mainly consume new knowledge. In this economy, the science and art practically become «direct productive forces» and a source of growth of public, collective and individual welfare, the development of abilities and opportunities of a person in his or her local, regional and global «smart» environment.

The material and non-material intellectual investment goods made and operated at the GES [14] micro-level by the quality human capital with an innovative character are the significant factors of the development of the knowledge-based economy. The development of such economics on the basis of combination of its production factors according to the theory of meta production function [26] assumes not only the creation and use of adequate equipment and materials connecting to a human factor in progressive technologies, but also the establishment of the corresponding relations between subjects of economic activity at different levels and in different scales for efficient realization of its particular properties. The factors of structuring, functioning and progressive evolution of the knowledge-based economy are appropriate forms of institution, organization and information.

The system of relations of production, distribution, exchange and consumption of new knowledge forms is a subject field of the knowledge-based economy. If the factors of production of knowledge consider as endogenous, it would be possible to allocate a core of specified subject and cognitive economy - its part presented by the directly labor relations of workers in the course of realization of their knowledge and competences.

The experiments conducted on imitating model of the participants' interaction of the knowledge-based economy show that its efficiency assumes observance of some optimum ratio between all categories of characters. As the quantity of knowledge is accepted an equal number of people, the knowledge-based economy gives as a significant volume of production, according to how much knowledge is created by scientists and how many people consumed this knowledge [13]. This property becomes a condition of emergence of a new form of the cooperation appropriate to the global nature and applicable to specifics of different spheres, branches, sectors and segments of the knowledge-based economy - collaborations. This form of interactions of the subjects of the knowledge-based economy has been developing especially intensively since the beginning of the XXI century in countries with prevalence of a share of hi-tech sectors in gross domestic product, which has entered the VI technological mode on the basis of NBIC of convergence.

\section{Categorical characteristics of collaboration}

The collaboration as poorly studied, but quickly developing form of communications and relations between knowledge-based economy draws special attention not only of scientists and practicians among economists, but also politicians, lawyers, sociologists, psychologists, cultural specialists. Internet recorded rapid development of information about unity of variety of forms of collaboration in the theory and practice in the XXI century. There are possible to find million general and special websites devoted to this subject.

Talking about the nature and content, the collaboration is a process of joint labor, production or economic activity of two and more economic subjects (individual or group) for the general goal achievement. Using the principles of consent and trust there are a mutually advantageous exchange of knowledge, training of participants for their competences increasing, production of innovative products to a considerable intellectual component for market promotion and achievement of significant cumulative effects.

Talking of the phenomenon and form, the collaboration represents cooperation in a context of the knowledge-based economy and is concretized on subjects and objects, levels and scales, spheres and branches, sectors and GES segments. This specific form of cooperation training and generating new knowledge can be considered both at the level of particular workers and firms, or the whole states, their integration unions and investment alliances [4].

On the nanolevel, the collaboration has to be connected with separate operations, actions, receptions and even movements of its participants [5]. The collaboration develops in labor activity on workplaces of its direct participants in various stages of processes of the manufacturing of the partial (intermediate) and final product in divisions of the enterprises, and also in interactions 
of firms as a managing form for ensuring mutual aid and solidarity on the markets of their goods.

Though the collaboration can exist at the contrast of an ultimate goal of its subjects, connecting them on the general requirement for the term of achievement of the intermediate purposes on the principles of mutual benefit and free will, but this on its part is studied poorly, and the concept of this context is used seldom. Probably, it is connected to its formation stage when all its internal contradictions have not happened yet.

At micro-level, the collaboration is a convergence of interests of the most advanced subjects of the global economic system, which is looking for innovative solutions of modernization or transformation of composition and structure of goods made by creation of the following generations (more perfect generation of different level and scale). At the same time, it is obvious that the products of a new generation (mega-, macro - meso, micro levels) and principles absorb the achievements of the previous ways for a particular and required degree, which have been saved up during all of GES evolution. The relevant and previous ways or generation of different levels defines dominating advantages of the goods created in their framework: specifics of its usefulness and cost that will be inevitably expressed in its value and competitiveness.

There are the formal and real collaborations as it is not enough the legal agreement and contractual registration for collaboration and its desirable result. Only in the course of real, active collaborations as a result of interaction of all required and sufficient factors of work and production of its result - mutual training of participants and their general product with the new intellectual component - can be received. It could be argued that such product is the general result of the intellectualization of subjects and objects of production on the basis of this special form of cooperation of workers and staff, firms and their enterprises, corporations and states, their integration unions, bilateral and multilateral alliances.

The merging of participants' interests of collaboration can happen only when their cooperation has true mutual aid (according to P. Kropotkin one of the fundamental factors of mankind's evolution, so and global economic system). Mutual aid of participants of the collaboration is opposite to their competition dialectically, instead of antagonistic that allows to use both parties of interaction on achievement of the high result of cooperation. One of its important principles is the principle of equal income for all of the collaboration members after realization of their goods in the market. In this way, there is no difference with cooperation. As the essential social capital providing efficiency of collaboration, it is expedient to consider trust, which generates solidarity as the fastening relation of creativity within a collaboration. Solidarity is a required active sympathy of collaborators to the general actions and opinions on the basis of community and coordination of each interest.

Without mutual trust and solidarity the effective mutual training and the receiving the general intellectual product is not possible. As the arising braking mechanisms in cooperation will lead to the effect decrease and degeneration of collaboration. In this way, the parity between competition and partnership is broken.

Collaboration in latent, or the hidden, not observed form is a particular interest in the theory and practice. It nevertheless can be fixed indirectly in imitation of the best practicians of competitors. The other form is informal collaboration, which arises between partners in «the related groups» (the employees, teachers and pupils) when carrying out research and design works and receiving as an accompanying by-product of new knowledge and competences. It gives a grounding of collaboration registration of participants «informed» about each other on previous practicians during the work on the subsequent projects within the general group enterprises and firms, clusters and corporations and unions. At the same time, the latent period of collaboration can be considered as the incubation period of the emergence of new production way of a certain new product; it takes time between the beginning of cognitive influence of the initiator and the emergence of the response of the potential partner.

\section{Collaboration at the GES megalevel}

The knowledge-based economy underlies almost all megatrends of GES evolution at the present stage [6], and the relations of collaboration become an efficient form of their realization. The international collaboration has the priority value in the globalization conditions as megalevel institute. As it reflects the relations of the international public division of labor and target cooperation of the capitals of its subjects for the general problem solution in the knowledge-based economy on the basis of their agreement. Such form of the joint working of economic subjects of several countries (or the integration unions) is adequate to effective achievement of their general purposes of megaprojects in the sphere of the intellectual production manufacturing. $s$ it provides attraction, concentration and operation of their resources (intellectual human, technical, mate- 
rial, institutional, organizational and information), proceeding from the actual competitive advantages, which have developed and recognized by each participant. The joint resources created out of the capital holdings (investments) of participants and united in rational parameters in company created by participants (object of collaboration, independent from organizational and legal form) for megaproject implementation are the factors of megaproduction of new knowledge and competences, equipment and technologies, materials and information, norms and rules, communications and groups.

While, in the operation of international collaboration, the co-production, an exchange, distribution and consumption of knowledge and competences by agents representing its participants are carried out. Important line of such collaboration is the simultaneous characteristics' combination of the subject, project, object and process of megaeconomic system in which its cooperative cognition, or mutual participants' training according the principles of voluntariness and confidence is carried out.

The collaboration at the GES megalevel assumes the formation of the collective associated economic subject on the basis of multilateral cooperation both state, and the private companies in the conditions of preference and guarantees of their individual and general basing by the states. The new subject creates a set of agreements for purposeful implementation of the main and auxiliary projects. The certain object of the collective using and the possession, generating commodity objects and bringing effects at market realization at the GES megalevel is the result of projects' implementation on the basis of collaboration. It demands the governing body though the general management can be public at the cooperation of equal members of the world community.

Undoubtedly, the participants of collaboration can have more opportunities of successfull achievement in the conditions of the global competition at the megaeconomic level for limited planet resources. Thus, the international collaboration is the megaeconomic form of the international cooperation in a scientific and technical field of activity for ensuring creation and progress of the advanced knowledge and technologies by the countries and firms in economics and world markets.

As an instrument for company's cooperation in the knowledge-based economy for the receiving of a new intellectual product, in the interests of participants collaboration can extend on any creative sphere. It can be found in both the rational world (science and technologies) and in the emotional sphere (art and design). However, there is a general trend of the interrelation strengthening of its rational and emotional forms of realization. At the same time, it adapts and modifies at any GES level - from individual and local to regional, national or transnational.

The collaboration covers the main structure and infrastructure at all levels of the global economy. Beginning at the particular workplaces and local firms it extends through the regions and the whole world being embodied in intercompany and interstate agreements and projects, attracting large private investors in trade, transport, information, financial meganetworks and the megacenters for megaprojects' implementation.

A lot of collaborations provide both intensive, and extensive development of the VI technological mode, creating essentially new types of products or new generation of already let out products, modifying their components. It accelerates way of development at the time reduction of its achievement introduction and extend the sphere of its action attracting the new spheres of economics and life.

\section{Scientific collaborations and scientific megacenters}

The megasayens-centers (MSC) develop within the framework of the gaining momentum of VI technological mode on the principles of voluntary megadesign initiation by subjects of the international economic relations on the basis of collaboration. They can be defined as a large-scale megaeconomic form of investment cooperation of the intellectual products' production (knowledge and technologies) of the world value, which adequate to the knowledge-based economy, and based on the transnational or international capital [7].

MSC persistently are developed in research and design and cognitive activity, the creation of new knowledge and technologies, formation of new competences of staff and ways of cooperation with the national centers of shared use. This process is actively generated and stimulated by the countries leading of the VI technological mode. They since the beginning of the XXI century have found its way in the development strategy by the most progressive countries and their integration unions.

The main sense and purpose of scientific collaborations (the centers and concerns) consists in the decrease by their participants of transformational and transaction expenses, increase of development efficiency and the contributing to accomplishments of scientific and technical progress of the world community. The training of the 
next generation scientists with the interdisciplinary competences, ready to work at the breakthrough directions, to use new methods of transformation of substance and a field, involve new materials is an important problem of such creative design associations.

Therefore, the MSC used in the world practice can be characterized as large research centers with equipment intended for collective (international) using. Such kind of equipment is very expensive equipment of higher complexity and inaccessible to separate scientific institutes - large scientific and technical complexes (astrophysical installations, neutron sources, nuclear and physical installations, installations with counter bunches for physics of high energy, thermonuclear installations, powerful lasers, sources of radiation, lasers on free electrons, installations with super strong magnetic fields, etc.). The cost of such equipment is over 200 million U.S. dollars [1].

For example, the mega collaboration of CALICE (Calorimeter for the LInear Collider with Electrons) unites more than 300 physicists and engineers from 57 institutes of 17 countries. Its main objective is the creation, testing and optimization of a calorimetric system of future detector for ILC. Within this collaboration, some prototypes both electromagnetic, and hadron calorimeters, including an analog hadron calorimeter with the unprecedented granularity, which has active ITEF-made elements (detecting layers) were created and tested on the test beams. The calorimeters worked as a part of an experimental installation in DESY, CERN and FNAL laboratories in 2006-2010. The great volume of experimental data - a hundred of million events in electron beams, positrons, pi mesons and muons in the energy range from 2 to $130 \mathrm{GEV}$ [16] was collected.

The European x-ray laser on XFEL free electrons (X-ray free-electron laser) [24], Germany; Large Hadron Collider of LHC (Large Hadron Collider) [28] in the European Council for Nuclear Research (Conseil Européen pour la Recherche Nucléaire - CERN), Switzerland; thermonuclear ITER reactor (International thermonuclear experimental reactor) [27], France; High-Intensity Heavy Ion Accelerator Facility of FAIR (Facility for Antiproton and Ion Research) [25], Multicharged Ions Research Center (GSI, Darmstadt, Germany) are examples of scientific collaboration.

Such groups of international collaborations as MINOS, ASACUSA, OPERA [20], ATLAS, EAGLE, ASCOT [23], Belle work actively developing physical research. Clearly, temporary creative groups of experts from different countries solve certain partial issues within the general project. The gen- eral project is organized in the form of the international collaboration of higher level, scale, and term with other institutions and authorities of subject-object characteristic. The analysis shows the hierarchy of collaboration structure, and also the subordination of processes and results, objects and subjects, projects and effects in the solution of its private and general issues.

Except the described ones there are new collaborations appearing in the Earth science. For example, the «Baikal» collaboration is aimed at Universe system studying, on one hand, and data acquisition in elementary-particle physics, on the other hand, is a single science dealing with the structure of matter on micro and macrolevel. The working meetings of «Baikal» collaboration conduct in Dubna 2 times a year. The collaboration includes JINR, The Institute for Nuclear Research of the Russian Academy of Sciences (Moscow), NIIYAF of the Moscow State University, RNTs «Kurchatov Institute», the German research center DESY (office in Tsoyten), Irkutsk and Nizhny Novgorod State Universities, the St. Petersburg State Marine Technical University. Regularly the participants intensively discuss and analyze work results of the different groups of the collaboration members, draw up long-term plans for half a year, discuss the forthcoming expeditions. Parallel with equipment evolution, there is also an ideological maturing of researchers: it becomes clearer what technical tasks should be solved and how to solve them correctly [9].

\section{Diffusion and collaboration prospect}

Collaboration distribution among a comprehensive range of life spheres and economic activity tends to be accelerated that corresponds to the first phase of the raising Kondratyev cycle stage (2000-2012). The level of its development in certain projects and field grew immensely in the two last decades, unlocking its creative and cognitive potential in short-term and long-term, local and global projects.

For the last decade, the collaboration has griped the sphere of mass consumption having accepted the industrial principles and purposes, mass character and distribution scales. More and more the collaboration gets into the intellectual solution of the daily problems of the modern man, and it is not strange. Here, the knowledge-based economy nominates this form of cooperation for the sake of the receiving the creative and effective intellectual product to the foreground. As it becomes a way to overcome routine and answers innovative approach in the solution of perspective daily tasks. 
The collaboration most quickly develops in the sphere of architecture and art, fashion and music, landscape and construction design, production of footwear and clothes, logistics and trade, ICT and mass media, creation of new PC and IP, cars and other [3]. An example from the media sphere: the Very Nearly Almost magazine presented the next collaboration with street artists, and the advertising of its No. 22 was made by the British of «Soulful Creative,» which created a very original wall having united in one work an illustration, classical graffiti, the art of creation of signs and design [18]. Another example - the Amaze Art project (it is founded in 2012), which is engaged in the synthesis of the modern art and design. The project has several collaborations with the various artists aimed at the union of crafts and arts. Among the others, there is a famous street artist named Tilt, whose skill was commercially successfully presented in new forms of furniture [10].

K. Lagerfeld, M. Katranza, A. Bittar, I. Maran have got involved using the capacity of collaboration in a fashion industry. There are a whole lot of examples of creative cooperation in all kinds of combinations of ideas and competences. So, 2012 Marni, Maison Martin Margiela [17] is marked with effective collaborations of $\mathrm{H} \& \mathrm{M}$ with Versace. The well-known model K. Moss took part in the joint project with the French sushi chain restaurants of Sushi Shop, having created design of a unique box for sushi. It is not for the first time «Sushi Shop» has «collaborations with the celebrities». Musician L. Kravitz and designer K. Takada were the first who made a box for restaurants . Nowadays, due to the opening of the first place in London (and the 100-Th - in the world), bosses of the French chain have decided to involve the most fashionable British in cooperation.

The creation of new products on the basis of collaboration of well-known companies from the different countries and fields (for instance, production of glamorous Italian cars - Ferrari, and a Swiss watch - Hublot) embodies their best achievements, becoming a sign for collections of judges of both brands (hours of Big Bang U.A.E. Limited Edition) [11]. Successful collaboration, arising within separate projects, can repeat in other projects with the same participants. Such examples are Nike and A.P.C in the design and production of sports shoes of a new generation. These firms after debut collaboration of 2012, being very successful, made the decision on continuation of cooperation within the commonwealth of firms of the USA and France at the creation of the new Nike Air Maxim 1 and Nike Dunk High collection. At the moment, there are only two shops located in Hong Kong (A.P.C. Central and A.P.C. Causeway Bay) provide this footwear. It is the strategy of the bringing a collaboration product to the global market.

Together with collaboration distribution in economic systems at all levels, and especially in the external economic relations of progressive companies of different countries, the tendency of vulgarization of this efficient organization form of creative activity was arisen. Nowadays single acts of interactions of particular economic subjects and actions of particular individuals (for instance «collaboration of trousers and scissors») refer to collaboration [21]. The set of vulgar definitions of collaboration explaining it as the training cooperation in general [8] is made. Therefore, collaboration is reduced and loses its specifics as any cooperation trains something new its participants. But not any cooperation is organized to receive the general intellectual product and the corresponding cognitive effects for its participants. However, there is a lot of waste at the beginning of the process while removal and disclosure of the new concept.

On November 26, 2012 Google created the site «the Collaboration Project», where following definition is made: «The collaboration is a trend of our present. Nowadays it is fashionable to be united for experience exchange and carrying out projects. This very rare combination is fashionable and useful. We invite you to contribute to someone's development and grow professionally participating in our events» [19]. Such promoting with fund raising (!) in favor of collaboration yet have not borne unique fruits, but, probably, after some time it will be a form of new national and international industrial scale.

However, the collaboration becomes increasingly significant. Not only in economics, but also in social life where the social clusters, territorial organizations of self-management, volunteer initiatives are organized. At the same time, the government has a lack of creative ideas and efficient solution, new intellectual resources, efficient ways of their innovative mobilization for authorities' support of civil society in search of perspective trajectories of development of the countries and regions, strategies of economic evolution [22] are required. Collaboration forms of social life and social networks becomes an object of study of many humanities and social sciences - from psychology, philology and cultural science to sociology, political science and law.

From a position of cognitive and heuristic, pragmatical and predictive aspects the collaboration as a global form of the organization of the 
knowledge-based economy with all of its system problems and contradictions, advantages and effects, scales and forms still should be studied deeply not only in the economic science field, but also in an interdisciplinary context. Along the way, undoubtedly, the new sides of its potential, prospect and application limits will be revealed. They are going to become a part of the evolutionary economic theory, policy and practice.

\section{References}

1. V Akademgorodke mozhet poyavitsya «innovatsionnaya» tamozhnya [In Academic town «innovation» customs can appear]. Takhnopark Novosibirsskogo Akademgorodka [Techno-park of Novosibirsk Academic town]. Available at: http://www.int-park. com/index.php?id=stat\&show=1154 (date of access: 10.06 .2013 ).

2. Vtoraya kollaboratsiya Saucony i peterburgskoy marki Anteater [The second collaboration Saucony and St. Petersburg brand Anteater]. Available at: http://sobaka.ru/fashion/news/16554 (date of access: 20.06.2013).

3. Dzhinsy dlya modeli. Kollaboratsiya Karli Kloss i Frame [Jeans for a model: collaboration Karlie Kloss and Frame]. Available at: http://www.justlady.ru/news-162709-dzhinsy-dlya-modeli-kollaboraciya-karli-kloss-i-frame (date of access 10.06.2013).

4. Inshakov O. V. (2004). Urovnevyy analiz obekta, predmeta i metoda ekonomicheskoy teorii [The level - sensitive analysis of the object, subject and method of economic theory]. Izvestiya Sankt-Peterburgskogo universiteta ekonomiki i finansov [Izvestia of St. Petersburg university of economics and finances], 4(40), 5-18.

5. Inshakov O. V. (2006). Evolyutsionnaya ekonomika i ekonomicheskaya genetika [Evolutional economy and economic genetics]. VI Mezhdunarodniy simpozium po evolyutsionnoy ekonomiki [VI International symposium on evolutional economy]. Moscow: IE RAN, 45-58.

6. Inshakov O., Voloshin A. (2012). Formirovaniye kontseptsii megatrendov evolyutsii globalnoy ekonomicheskoy sistemy [Formation of the concept of megatrends evolution of the global economic system]. Ekonomika. Nalogi. Pravo [Economy. Taxes. The right], 5, 61-70.

7. Inshakova E., Inshakov O. (2012). Vzaimodeystvie institutov razvitiya nanoindustrii v makroekonomicheskom i megaeknomicheskom masshtabe [Interaction between institutes of developing nanoindustry in microeconomic and megaeconomic scope]. Vstnik Volgogradskogo gosudarstvennogo universiteta. Seriya 3: Ekonomika. Ekologiya [Vestnik VOLGU. Ser.3: Economy. Ecology], Issue 1 (20), 298-304.

8. Kollaboratsiya [Collaboration]. Available at: http://letopisi.ru/index.php/Коллаборация (date of access: 10.06.2013).

9. Kollaboratsiya «Baikal»: stantsiya rabotaet rkruglogodichno [Collaboration «Baikal»: the station is accessible all the year round]. (2010). Dubna. Ezhenedelnik Obedinyonnogo instituta yadernykh issledovaniy [«DUBNA», JINR], 26(4016). Available at: http://wwwinfo.jinr.ru/ jinrmag/win/2010/26/ba26.htm (date of access: 20.06.2013).

10. Kollaboratsiya Amaze и Tilt [Collaboration Amaze and Tilt]. Available at: URL: http://www.creammag.ru/posts/art/graffiti/ kollaboraciya-amaze-i-tilt/

11. Kollabratsiya Hublot и Ferrari - часы Big Bang U.A.E. Limited Edition [Collaboration Hublot и Ferrari — watches Big Bang U.A.E. Limited Edition]. Available at: http://www.hautetime.ru/kollaboratsiya-hublot-i-ferrari-chasy-big-bang-u.a.e.-limited-edition/21387/ (date of access 10.06.2013).

12. Letnyaya kollaboratsiya Nike v sotrudnichestve s A.R.S. [Summer Collaboration Nike in cooperation with A.P.C.]. Available at: http://afisha.bigmir.net/shopping/news/198941-Letnjaja-kollaboracija-Nike-v-sotrudnichestve-s-A-P-C- (date of access: 20.06.2013).

13. Makarov V.L. (2003). Ekonomika znaniy. Uroki dlya Rossii [The economy of knowledge: lessons for Russia]. Vestnik Rossiyskoy akademii nauk [Vestnik of the Russian Academy of Sciences], Vol. 73, 5, 450-456.

14. Makarov V.L., Kleiner G. B. (2007). Mikroekonomika znaniy [Microeconomy of knowledge]. Moscow, ZAO "Izdatelstvo "Ekonomika" [CJSC «Publishing House «Economcs»], 279.

15. Master-klass “Kollaboratsiya 2013" [Masterclass «Collaboration 2013»]. Available at: http://vk.com/event48387951. (date of access: 10.06.2013).

16. Mezhdunarodniy leniyniy kollayder [International linear collider]. Kollaboratsiya CALICE [Collaboration CALICE]. Available at: http://www.desy.de/ chadeeva/itep_win/calice.html. (date of access: 10.06.2013).

17. Novaya kollaboratsiya: H\&M i Isabel Maran [New collaboration H\&M and Isabel Maran]. Available at: thttp://www.woman. $\mathrm{ru} /$ fashion/medley3/article/92964/ (date of access: 10.06.2013).

18. Ocherednaya kollaboratsiya VNA s ulichnymi khudozhnikami [Regular collaboration VNA with street artists]. Available at: http://www.creammag.ru/posts/art/graffiti/ocherednaya-kollaboraciya-vna-s-ulichnymi-hudojnikami (date of access: 20.06.2013).

19. Proekt Kollaboratsiya [Project: Collaboration]. Available at: http://checkthis.com/collaboration. (date of access: 20.06.2013).

20. Sovremennaya kosmologiya [Modern cosmology]. Available at: http://www.modcos.com/finds.php?teg_ $\mathrm{c}=\% \mathrm{D} 0 \% \mathrm{BA} \% \mathrm{D} 0 \% \mathrm{BE} \% \mathrm{D} 0 \% \mathrm{BB} \% \mathrm{D} 0 \% \mathrm{BB} \% \mathrm{D} 0 \% \mathrm{~B} 0 \% \mathrm{D} 0 \% \mathrm{~B} 1 \% \mathrm{D} 0 \% \mathrm{BE} \% \mathrm{D} 1 \% 80 \% \mathrm{D} 0 \% \mathrm{~B} 0 \% \mathrm{D} 1 \% 86 \% \mathrm{D} 0 \% \mathrm{~B} 8 \% \mathrm{D} 1 \% 8 \mathrm{~F}+\mathrm{MI}-$ NOS\&page $=1 \&$ refs $=$ news. (date of access: 10.06 .2013 ).

21. Shorty na kortakh. Kollaboratsiya stanov i nozhnits [Shorts on courts. Collaboration of pans and scissors]. Available at: http://downtown.ru/voronezh/fashion/1864 (date of access: 20.06.2013).

22. Shustov Ya. Intellegentsiya i kollaboratsiya [Intellectuals and collaboration]. Available at: http://www.liberty.ru/Themes/ Intelligenciya-i-kollaboraciya (date of access: 20.06.2013).

23. Eksperiment ATLAS [Experiment ATLAS]. Available at: http http://ru.wikipedia.org/wiki/Эксперимент_ATLAS (date of access: 20.06.2013).

24. European XFEL [сайт]. URL: https://www.xfel.eu/ (дата обращения 20.06.2013).

25. Facility for Antiproton and Ion Research. Available at: http://www.fair-center.eu/ (date of access: 20.06.2013). 
26. Inshakov O. The Theory of Human Action and Economic Genetics // The Human Being in Contemporary Philosophical Conceptions. - Cambridge Scholars Publishing, 2009. - P. 159-171.

27. ITER - the way to new energy. Available at: http://www.iter.org/ (date of access: 20.06.2013).

28. The Large Hadron Collider // CERN [Electronic resource]. URL: http://home.web.cern.ch/about/accelerators/large-hadron-collider (date of access: 20.06.2013).

\section{Information about the author}

Inshakov Oleg Vasilyevich (Volgograd, Russia) - Doctor of Economics, Professor, Rector, Volgograd State University (100 Prospekt Universitetskiy, Volgograd, 400062, Russia, e-mail: rector@volsu.ru). 